$\underline{\text { Leading Article }}$

\title{
Current update on diagnosis and management of neuroblastoma
}

Julius Scott ${ }^{1}$

Sri Lanka Journal of Child Health, 2016; 45(4): 241-246

DOI: http://dx.doi.org/10.4038/sljch.v45i4.8182

(Key words: Neuroblastoma, diagnosis, management)

Neuroblastoma is the commonest extracranial solid tumour in children originating in the adrenal medulla or paraspinal area where the sympathetic nervous system is present. There is no known risk factor that predisposes to its development. However, about $1-2 \%$ of children with neuroblastoma have a family history of it. Familial neuroblastoma is a very rare association of congenital central hypoventilation syndrome ${ }^{1}$.

\section{Clinical presentations}

Common clinical presentations of neuroblastoma $a^{2,3}$ are summarized in table 1 .

Table 1: Clinical presentations of neuroblastoma

- Abdominal distention

- Bone pain

- Cytopenia

- Fever

- Hypertension

- Horner syndrome

- Subcutaneous skin nodules

- Proptosis

- Periorbital ecchymosis

- Paralysis due to spinal cord compression

- Watery diarrhoea due to secretion of vasoactive intestinal peptide by tumour

- Opsoclonus / myoclonus syndrome

Paraneoplastic neurologic findings, including cerebellar ataxia and opsoclonus/myoclonus, are rare manifestations. These are frequently associated with neurologic and cognitive deficits, including psychomotor retardation. However, children with opsoclonus/myoclonus syndrome often have a primary tumour with favourable biological features carrying a good prognosis ${ }^{4}$.

${ }^{1}$ Senior Consultant, Paediatric Oncologist, Department of Paediatric Haematology and Oncology and Bone Marrow Transplant Services, Global Health City, Chennai, Tamilnadu, India

*Correspondence: jxscott@hotmail.com

The author declares that there are no conflicts of interest.

Open Access Article published under the Creative Commons Attribution CC-BY (c) (P) License

\section{Diagnosis}

Diagnostic modalities of neuroblastoma ${ }^{5,6}$ include:

- Urine catecholamines: Urinary excretion of catecholamine metabolites vanillylmandelic acid (VMA) and homovanillic acid (HVA) will be elevated in neuroblastoma.

- Metaiodobenzylguanidine (MIBG) scan: On nuclear medicine imaging, $95 \%$ of neuroblastoma will show positivity

- Imaging of the primary tumour: Computed tomography or magnetic resonance imaging (MRI) with contrast are used. Paraspinal tumours threatening to compress the spinal cord are best imaged using MRI.

- Biopsy: Tumour tissue is necessary for obtaining biological data to assign riskgroups. To test for $M Y C N$ amplification and $1 \mathrm{p} / 11 \mathrm{q}$ loss of heterozygosity on involved bone marrow, a minimal $30-40 \%$ tumour involvement is needed.

Minimum criteria for diagnosis of neuroblastoma include one of the following:

1. Unambiguous histopathologic diagnosis from tumour tissue by light microscopy, with or without immunohistochemistry, or increased levels of serum catecholamines (dopamine \& norepinephrine) or urinary catecholamine metabolites (VMA or HVA).

2. Combination of bone marrow aspirate or trephine biopsy containing unambiguous tumour cells and increased levels of serum catecholamines or urinary catecholamine metabolites $^{7,8}$.

\section{Prognosis}

This is associated with:

- $\quad$ Age / stage at diagnosis: All children with localized neuroblastoma and children aged 18 months or less with advanced disease and favourable disease characteristics have a good prognosis.

- Site of the primary tumour: Adrenal (rather than non-adrenal) primary tumours, and non-thoracic (rather than thoracic) primary tumours, will more probably be associated with unfavourable features, such as $M Y C N$ amplification, even after allowing for age, stage and histology. 
- Tumour histology: Cellular differentiation and maturation, Schwannian stroma and cystic neuroblastoma are considered as prognostically favourable histological features, whereas mitosis and karyorrhexis are considered as prognostically unfavourable histological features ${ }^{9,10}$.

- Regional lymph node involvement: Whilst involvement ipsilateral to the primary tumour has no effect on prognosis, involvement contralateral to the primary tumour denotes a poor prognosis.

- Response to treatment: In high-risk neuroblastoma, residual disease in bone marrow following induction is associated with a poor prognosis. Similarly, persistence of MIBG-avid tumour after induction is over indicates a poor $\operatorname{prognosis}^{11,12}$.

- Biological features such as MYCN amplification and Ploidy: MYCN amplification is detected in 16-25\% of tumours. In stages 2, 3, 4, and $4 \mathrm{~S}$, amplification of the $M Y C N$ gene predicts a very poor prognosis. In addition to deletion of chromosome $1 \mathrm{p}$, amplification of the MYCN gene is associated with gain of the long arm of chromosome 17 (17q), which independently indicates a poor prognosis $^{13,14}$. Ploidy is the amount of chromosomal material in a cell. Normal human cells are diploid, receiving a full set of chromosomes from each parent. In many human cancers, cells are no longer diploid but have lost or gained DNA during mutation. This is called aneuploidy ("without normal ploidy"). Cancer cells gaining genetic material are called hyperdiploid ("more than diploid") and those losing genetic material are called hypodiploid. Ploidy is a useful marker especially in $4 \mathrm{~S}$ patients and other infants ${ }^{15,16}$.

\section{Staging}

The staging of neuroblastoma is summarized in table 2:

Table 2: International Neuroblastoma Staging System (INSS)

\begin{tabular}{|c|l|}
\hline Stage & \multicolumn{1}{c|}{ Details } \\
\hline 1 & $\begin{array}{l}\text { Localized tumour with complete gross excision, with or without microscopic residual disease; } \\
\text { representative ipsilateral lymph nodes negative for tumour but nodes attached to and removed } \\
\text { with primary tumour may be positive. }\end{array}$ \\
\hline $2 \mathrm{~A}$ & $\begin{array}{l}\text { Localized tumour with incomplete gross excision; representative ipsilateral non adherent lymph } \\
\text { nodes negative. }\end{array}$ \\
\hline $2 \mathrm{~B}$ & $\begin{array}{l}\text { Localized tumour with or without complete gross excision, with ipsilateral non adherent lymph } \\
\text { nodes positive for tumour. Enlarged contralateral lymph nodes negative microscopically. }\end{array}$ \\
\hline 3 & $\begin{array}{l}\text { Unresectable unilateral tumour infiltrating across midline, with or without regional lymph node } \\
\text { involvement, or localized unilateral tumour with contralateral regional lymph node involvement, } \\
\text { or midline tumour with bilateral extension by infiltration (unresectable) or by lymph node } \\
\text { involvement. Midline is defined as vertebral column. }\end{array}$ \\
\hline 4 & $\begin{array}{l}\text { Dissemination to distant lymph nodes, bone, bone marrow, liver, skin, and/or other organs, } \\
\text { except as defined for stage 4S. }\end{array}$ \\
\hline $4 \mathrm{~S}$ & $\begin{array}{l}\text { Localized primary tumour, as defined for stage 1, 2A, or 2B, with dissemination limited to skin, } \\
\text { liver, and/or bone marrow (by definition limited to infants). Marrow involvement less than 10\%. }\end{array}$ \\
\hline
\end{tabular}

\section{Treatment overview}

Neuroblastoma treatment has evolved over the past few decades. The various risk groups in neuroblastoma as per Children's Oncology Group are summarized in tables 3, 4, and 5. Children were assigned to low, intermediate, or high risk group based on:
- International Neuroblastoma Staging System (INSS)

- Age

- International Neuroblastoma Pathologic Classification (INPC)

- Ploidy

- Amplification of the $M Y C N$ oncogene within tumour tissue ${ }^{17,18}$

Table 3: Low risk neuroblastoma

\begin{tabular}{|l|c|c|c|c|}
\hline \multicolumn{1}{|c|}{ INSS } & Age & MYCN status & INPC & DNA Ploidy b \\
\hline Stage 1 & $0-21$ years & Any & Any & Any \\
\hline \multirow{3}{*}{ Stage 2A/2Bc } & Less than 365 days & Any & Any & Any \\
\cline { 2 - 5 } & 365 days-21 years & Non amplified & Any & - \\
\cline { 2 - 5 } & & Amplified & Favourable & - \\
\hline Stage 4Sd & Less than 365 days & Non amplified & Favourable & More than 1 \\
\hline
\end{tabular}


Table 4: Intermediate risk neuroblastoma

\begin{tabular}{|l|c|c|c|c|}
\hline \multicolumn{1}{|c|}{ INSS } & Age & MYCN status & INPC & DNA Ploidy b \\
\hline \multirow{2}{*}{ Stage 3c } & Less than 365 days & Non amplified & Any & Any \\
\cline { 2 - 5 } & 365 days-21 years & Non amplified & Favourable & - \\
\hline Stage 4c & Less than 548 days & Non amplified & Any & Any \\
\hline \multirow{2}{*}{ Stage 4Sd } & Less than 365 days & Non amplified & Any & -1 \\
\cline { 2 - 5 } & Less than 365 days & Non amplified & Unfavourable & Any \\
\hline
\end{tabular}

Table 5: High risk neuroblastoma

\begin{tabular}{|l|c|c|c|c|}
\hline \multicolumn{1}{|c|}{ INSS } & Age & MYCN status & INPC & DNA Ploidy b \\
\hline Stage 2A/2B b & 365 days- 21 years & Amplified & Unfavorable & - \\
\hline \multirow{3}{*}{ Stage 3c } & Less than 365 days & Amplified & Any & Any \\
\cline { 2 - 5 } & 365 days-21 years & Non amplified & Unfavorable & - \\
\cline { 2 - 5 } & 365 days-21 years & Amplified & Any & Any \\
\hline \multirow{2}{*}{ Stage 4c } & Less than 365 days & Amplified & Any & Any \\
\cline { 2 - 5 } & 548 days - 21 years & Any & Any & Any \\
\hline Stage 4S & Less than 365 days & Amplified & & \\
\hline
\end{tabular}

Treatment options for neuroblastoma are summarized in table 6.

Table 6: Various treatment categories of neuroblastoma

\begin{tabular}{|l|l|}
\hline \multicolumn{1}{|c|}{ Risk group } & \multicolumn{1}{c|}{ Treatment } \\
\hline Low risk (overall survival 95\%) & $\begin{array}{l}\text { Surgery followed by observation. } \\
\text { Chemotherapy with or without surgery }\end{array}$ \\
\hline Intermediate risk (overall survival 70-80\%) & $\begin{array}{l}\text { Chemotherapy with or without surgery. } \\
\text { Surgery only }\end{array}$ \\
\hline High risk (overall survival 40\%) & $\begin{array}{l}\text { A regimen of chemotherapy, surgery, stem cell therapy, } \\
\text { radiation therapy and anti-GD2 antibody ch14.18, with } \\
\text { interleukin-2/GM-CSF and isotretinoin. }\end{array}$ \\
\hline Stage 4S (overall survival 90\%) & $\begin{array}{l}\text { Only supportive care } \\
\text { Chemotherapy (for symptomatic patients, very young } \\
\text { infants, or those with unfavourable biology). }\end{array}$ \\
\hline
\end{tabular}

\section{Surgery}

In patients without metastases, initial surgery is done to:

- obtain adequate tissue for biological studies and confirmation of diagnosis.

- resect as much primary tumour as is safely possible.

- sample regional lymph nodes not adherent to the tumour.

\section{Radiation therapy}

In low or intermediate risk neuroblastoma, radiation therapy is only used for symptomatic lifethreatening or organ-threatening tumour bulk not responding rapidly enough to chemotherapy. Common indications for radiation therapy are:

- Infants 60 days of age or less with stage $4 \mathrm{~S}$ and marked respiratory compromise from liver metastases which have not responded to chemotherapy.

- Symptomatic spinal cord compression which has not responded to initial chemotherapy and/or surgical decompression.

\section{Chemotherapy}

Carboplatin, cyclophosphamide, doxorubicin, and etoposide are widely used. Patients who have tumours with unfavourable biology are given 8 cycles of chemotherapy in comparison to 4 cycles for patients who have tumours with favourable biology usually in intermediate risk group.

High risk group treatment

Treatment for high-risk group usually consists of 3 phases:

- Induction

- Consolidation

- Maintenance

Induction phase: The most frequently used induction therapy comprises dose intensive cycles of cisplatin and etoposide alternating with vincristine, cyclophosphamide and doxorubicin. In some places topotecan is added to this regimen due to the anti-neuroblastoma activity seen in relapsed patients. After adequate response to chemotherapy, resection of the primary tumour is usually attempted $^{19-21}$. 
Consolidation phase: This involves myeloablative chemotherapy and HSCT, which try to eradicate minimal residual disease using lethal doses of chemotherapy and autologous stem cells collected during induction chemotherapy to repopulate the bone marrow. Several large randomized controlled trials have shown improved 3-year event free survival (EFS) for HSCT (31\% to $47 \%$ ) compared to conventional chemotherapy (22\% to $31 \%)^{22,23}$.

Maintenance phase: After recovery from myeloablative chemotherapy and HSCT, patients are treated with the differentiating agent oral isotretinoin for 6 months. Immunotherapy is given along with differentiated therapy using antibodies developed to target GD2, present on the surface of neuroblastoma cells. For high risk-patients in remission following $\mathrm{HSCT}$, chimeric anti-GD2 antibody ch14.18 combined with GM-CSF and IL2 are given in concert with isotretinoin and have been shown to improve EFS $^{24,25}$.

\section{Treatment options for stage 4S neuroblastoma} These include:

- Observation only with supportive care: Most patients do not require therapy unless bulk disease is causing organ compromise and risk of death.

- Chemotherapy: Infants with hepatomegaly or those less than 2 months old, can rapidly deteriorate and may benefit from early initiation of therapy. Various chemotherapy regimens have been used in this situation ${ }^{26}$.

\section{Treatment of spinal cord compression}

Immediate treatment is indicated and given because neurologic recovery is more likely when symptoms are present for a relatively short time before diagnosis and treatment. Children with severe spinal cord compression not promptly improving or those with worsening symptoms may benefit from neurosurgery. Laminectomy may result in later kyphoscoliosis and may not eliminate need for chemotherapy $^{27,28}$.

\section{Spontaneous regression of neuroblastoma}

Spontaneous regression usually occurs only in tumours with features such as:

- Near triploid number of chromosomes.

- No N-Myc amplification.

- No loss of chromosome 1p.

Infants with asymptomatic, small, low-stage adrenal neuroblastoma detected by screening or during prenatal or incidental ultrasound examination often spontaneously regress and may be observed safely without surgical intervention or tissue diagnosis ${ }^{29-31}$.
Neuroblastoma screening

Current data do not support neuroblastoma screening ${ }^{32}$.

\section{References}

1. Mosse YP, Laudenslager M, Khazi D, et al. Germline PHOX2B mutation in hereditary neuroblastoma. American Journal of Human Genetics 2004; 75(4): 727-30.

http://dx.doi.org/10.1086/424530

PMid: 15338462 PMCid: PMC1182065

2. Bourdeaut F, de Carli E, Timsit S, et al. VIP hypersecretion as primary or secondary syndrome in neuroblastoma: A retrospective study by the Société Française des Cancers de l'Enfant (SFCE). Pediatric Blood Cancer 2009; 52(5): 58590.

http://dx.doi.org/10.1002/pbc.21912

PMid: 19143025

3. Mahoney NR, Liu GT, Menacker SJ, et al. Pediatric Horner syndrome: Aetiologies and roles of imaging and urine studies to detect neuroblastoma and other responsible mass lesions. American Journal of Ophthalmology 2006; 142(4): 651-9. http://dx.doi.org/10.1016/j.ajo.2006.05.04 7

PMid: 17011859

4. Matthay KK, Blaes F, Hero B, et al. Opsoclonus myoclonus syndrome in neuroblastoma a report from a workshop on the dancing eyes syndrome at the advances in neuroblastoma meeting in Genoa, Italy, 2004. Cancer Letters 2005; 228(1-2): 275-82.

http://dx.doi.org/10.1016/j.canlet.2005.01. 051

PMid: 15922508

5. Yang J, Codreanu I, Servaes S, et al. I-131 MIBG post-therapy scan is more sensitive than I-123 MIBG pre-therapy scan in the evaluation of metastatic neuroblastoma. Nuclear Medicine Communications 2012; 33(11): 1134-7.

http://dx.doi.org/10.1097/MNM.0b013e32 $83570 \mathrm{ffe}$

PMid: 22825037

6. Jennings RW, LaQuaglia MP, Leong K, et al. Fetal neuroblastoma: Prenatal diagnosis and natural history. Journal of Pediatric Surgery 1993; 28(9): 1168-74. 
http://dx.doi.org/10.1016/00223468(93)90 $157-\mathrm{G}$

7. Cohn SL, Pearson AD, London WB, et al. The International Neuroblastoma Risk Group (INRG) classification system: an INRG Task Force report. Journal of Clinical Oncology 2009; 27(2): 289-97. http://dx.doi.org/10.1200/JCO.2008.16.67 85

PMid: 19047291 PMCid: PMC2650388

8. Brodeur GM, Pritchard J, Berthold F, et al.: Revisions of the international criteria for neuroblastoma diagnosis, staging, and response to treatment. Journal of Clinical Oncology 1993; 11(8): 1466-77.

PMid: 8336186

9. Kubota M, Suita S, Tajiri T, et al.: Analysis of the prognostic factors relating to better clinical outcome in ganglioneuroblastoma. Journal of Pediatric Surgery 2000; 35(1): 92-5. http://dx.doi.org/10.1016/S00223468(00)8 0021-4

10. Peuchmaur M, d'Amore ES, Joshi VV, et al.: Revision of the International Neuroblastoma Pathology Classification: confirmation of favourable and unfavourable prognostic subsets in ganglioneuroblastoma, nodular. Cancer 2003; 98(10): 2274-81.

http://dx.doi.org/10.1002/cncr.11773

PMid: 14601099

11. Yoo SY, Kim JS, Sung KW, et al.: The degree of tumour volume reduction during the early phase of induction chemotherapy is an independent prognostic factor in patients with high-risk neuroblastoma. Cancer 2013; 119(3): 656-64.

http://dx.doi.org/10.1002/cncr.11773

PMid: 14601099

12. George RE, Perez-Atayde AR, Yao X, et al.: Tumour histology during induction therapy in patients with high-risk neuroblastoma. Pediatric Blood Cancer 2012; 59(3): 506-10,

http://dx.doi.org/10.1002/pbc.24013

PMid: 22162143

13. Bagatell R, Beck-Popovic M, London $\mathrm{WB}$, et al.: Significance of $\mathrm{MYCN}$ amplification in international neuroblastoma staging system stage 1 and 2 neuroblastoma: a report from the International Neuroblastoma Risk Group database. Journal of Clinical Oncology 2009; 27(3): 365-70.

http://dx.doi.org/10.1200/JCO.2008.17.91

84

PMid: 19047282 PMCid: PMC2651034

14. Cotterill SJ, Pearson AD, Pritchard J, et al.: Clinical prognostic factors in 1277 patients with neuroblastoma: results of The European Neuroblastoma Study Group 'Survey' 1982-1992. European Journal of Cancer 2000; 36(7): 901-8. http://dx.doi.org/10.1016/S09598049(00)0 0058-7

15. Look AT, Hayes FA, Nitschke R, McWilliams NB, Green AA. Cellular DNA content as a predictor of response to chemotherapy in infants with unresectable neuroblastoma. New England Journal of Medicine 1984; 311:231-5.

http://dx.doi.org/10.1056/NEJM19840726 3110405

PMid: 6738617

16. Look AT, Hayes FA, Shuster JJ, Douglass EC, Castleberry RP, Bowman LC, et al. Clinical relevance of tumour cell ploidy and N-myc gene amplification in childhood neuroblastoma: a Pediatric Oncology Group study. Journal of Clinical Oncology 1991; 9:581-91. PMid: 2066755

17. Speleman F, Park JR, Henderson TO. Neuroblastoma: A Tough Nut to Crack. American Society of Clinical Oncology Education Book 2016; 35:e548-57. http://dx.doi.org/10.14694/EDBK_159169 PMid: 27249766

18. Mei H, Lin ZY, Tong QS. Risk stratification and therapeutics of neuroblastoma: the challenges remain. World Journal of Pediatrics 2016; 12(1):5-7.

http://dx.doi.org/10.1007/s12519-0160001-6

PMid: 26782342

19. Kushner BH, LaQuaglia MP, Bonilla MA, et al.: Highly effective induction therapy for stage 4 neuroblastoma in children over 1 year of age. Journal of Clinical Oncology 1994; 12(12): 2607-13.

PMid: 7527454

20. Park JR, Scott JR, Stewart CF, et al.: Pilot induction regimen incorporating pharmacokinetically guided topotecan for 
treatment of newly diagnosed high-risk neuroblastoma: a Children's Oncology Group study. Journal of Clinical Oncology 2011; 29 (33): 4351-7.

PMid: 7527454

21. Cheung NK, Heller G, Kushner BH, et al.: Stage IV neuroblastoma more than 1 year of age at diagnosis: major response to chemotherapy and survival durations correlated strongly with dose intensity. Progress in Clinical and Biological Research 1991; 366: 567-73.

PMid: 2068175

22. Matthay KK, Villablanca JG, Seeger RC, et al.: Treatment of high-risk neuroblastoma with intensive chemotherapy, radiotherapy, autologous bone marrow transplantation, and 13-cisretinoic acid. Children's Cancer Group. New England Journal of Medicine 1999; 341(16): 1165-73.

http://dx.doi.org/10.1056/NEJM19991014 3411601

PMid: 10519894

23. Berthold F, Boos J, Burdach S, et al. Myeloablative mega-therapy with autologous stem-cell rescue versus oral maintenance chemotherapy as consolidation treatment in patients with high-risk neuroblastoma: a randomised controlled trial. Lancet Oncology 2005; 6(9): 649-58.

http://dx.doi.org/10.1016/S14702045(05)7 0291-6

24. Yu AL, Gilman AL, Ozkaynak MF, et al. Anti-GD2 antibody with GM-CSF, interleukin-2, and isotretinoin for neuroblastoma. New England Journal of Medicine 2010; 363(14): 1324-34. http://dx.doi.org/10.1056/NEJMoa0911123 PMid: 20879881 PMCid: PMC3086629

25. Cheung NK, Cheung IY, Kushner BH, et al. Murine anti-GD2 monoclonal antibody 3F8 combined with granulocytemacrophage colony-stimulating factor and 13-cis-retinoic acid in high-risk patients with stage 4 neuroblastoma in first remission. Journal of Clinical Oncology 2012; 30 (26): 3264-70. http://dx.doi.org/10.1200/JCO.2011.41.38 07

PMid: 22869886 PMCid: PMC3434986
26. Hsu LL, Evans AE, D'Angio GJ: Hepatomegaly in neuroblastoma stage 4s: criteria for treatment of the vulnerable neonate. Medical and Pediatric Oncology 1996; 27(6): 521-8. http://dx.doi.org/10.1002/(SICI)1096911X (199612)27:6<521::AIDMPO3>3.3.CO;2Y

27. Katzenstein HM, Kent PM, London WB, et al.: Treatment and outcome of 83 children with intraspinal neuroblastoma: the Pediatric Oncology Group experience. Journal of Clinical Oncology 2001; 19(4): 1047-55.

PMid: 11181668

28. De Bernardi B, Pianca C, Pistamiglio P, et al.: Neuroblastoma with symptomatic spinal cord compression at diagnosis: treatment and results with 76 cases. Journal of Clinical Oncology 2001; 19(1): 183-90.

PMid: 11134211

29. Ambros PF, Brodeur GM: Concept of tumorigenesis and regression. In: Brodeur GM, Sawada T, Tsuchida Y: Neuroblastoma. New York, NY: Elsevier Science, 2000, pp 21-32.

30. Hiyama E, Hiyama K, Yokoyama T, et al.: Correlating telomerase activity levels with human neuroblastoma outcomes. Nature Medicine 1995; 1(3): 249-55.

http://dx.doi.org/10.1038/nm0395-249 PMid: 7585042

31. Brodeur GM, Minturn JE, Ho R, et al.: Trk receptor expression and inhibition in neuroblastomas. Clinical Cancer Research 2009; 15(10): 3244-50.

http://dx.doi.org/10.1158/10780432.CCR08-1815

PMid: 19417027 PMCid: PMC4238907

32. Woods WG, Gao RN, Shuster JJ, et al.: Screening of infants and mortality due to neuroblastoma. New England Journal of Medicine 2002; 346(14): 1041-6, http://dx.doi.org/10.1056/NEJMoa012387 PMid: 11932470 